\title{
IDENTIFIKASI IRIS DENGAN SNAKE MODEL-PSO DAN GABOR 2-D
}

\author{
I Gusti Ayu Agung Diatri Indradewi \\ Program Studi Teknik Informatika, STMIK STIKOM Indonesia \\ Denpasar, Indonesia \\ e-mail: diatri.indradewi@stiki-indonesia.ac.id
}

\begin{abstract}
Abstrak
Pada penelitian ini dibangun sistem identifikasi biometrik iris dengan menggunakan metode Snake Model-PSO dan Gabor 2-D. Tahap-tahap yang dilakukan pada penelitian ini terdiri dari akuisisi citra, pre-processing, segmentasi, ekstraksi ciri, dan pengenalan. Metode Snake Model-PSO diterapkan dengan memanfaatkan koordinat titik pusat pupil yang telah ditemukan sebelumnya. Proses ekstraksi ciri dilakukan dengan menggunakan tapis Gabor $2-D$ berukuran $33 \times 33$ dan sudut orientasi bernilai $90^{\circ}, 45^{\circ}, 0^{\circ}$, dan $-45^{\circ}$. Jumlah data referensi yang digunakan sebanyak 117 citra iris. Jumlah data uji yang digunakan sebanyak 78 citra iris. Berdasarkan hasil pengujian dapat disimpulkan bahwa persentase FMR sebesar $3,6737 \%$ dan FNMR sebesar $4,2735 \%$ untuk database iris kiri. Persentase FMR dan FNMR untuk database iris kanan menghasilkan yang sama, yakni $0 \%$. Unjuk kerja sistem berdasarkan akurasi keputusan menghasilkan persentase terbaik sebesar $91,0256 \%$ untuk database iris kiri dan $98,7179 \%$ untuk database iris kanan. Rata-rata waktu proses pada pendaftaran adalah 6,3109 detik, sedangkan pada identifikasi adalah 20,494 detik.
\end{abstract}

Kata kunci: iris, Snake Model-PSO, Gabor 2-D, FMR, FNMR

\begin{abstract}
In this research, the iris biometric identification system was developed by using the Snake Model-PSO and Gabor 2-D method. The steps taken in this research consist of image acquisition, pre-processing, segmentation, feature extraction, and introduction. The PSOSnake Model method is applied by utilizing the coordinates of the previously discovered pupil center point. The feature extraction process is performed by using a $33 \times 33$ Gabor 2-D filter and an orientation angle of $90^{\circ}, 45^{\circ}, 0^{\circ}$, and $-45^{\circ}$. The amount of reference data used is 117 iris images. The amount of test data used is 78 iris images. Based on the test results can be concluded that the percentage of FMR of $3.6737 \%$ and FNMR of $4.2735 \%$ for the left iris database. The percentage of FMR and FNMR for the right iris database yields the same, ie $0 \%$. System performance based on decision accuracy yielded the best percentage of $91,0256 \%$ for left iris database and $98,7179 \%$ for right iris database. The average processing time at registration is 6.3109 seconds, while the identification is 20.494 seconds.
\end{abstract}

Keywords : iris, Snake Model-PSO, Gabor 2-D, FMR, FNMR

\section{PENDAHULUAN}

Sistem biometrik menggunakan karakteristik fisiologis atau karakteristik perilaku untuk mengenali identitas seseorang. Karakteristik fisiologis adalah ciri fisik yang relatif stabil seperti sidik jari, geometri tangan, pola iris, dan retina.

Secara umum sistem biometrik dapat dibangun sebagai sistem verifikasi atau identifikasi. Sistem verifikasi merupakan sistem biometrik yang bertujuan untuk memberi penegasan berupa penerimaan atau penolakan terhadap identitas yang diklaim oleh seseorang. Sedangkan sistem identifikasi merupakan sistem biometrik yang bertujuan untuk mengungkap identitas seseorang (Putra, 2010).

Salah satu sistem biometrik yang paling menjanjikan adalah melalui salah satu bagian dari organ mata yaitu iris. Iris adalah daerah berbentuk gelang pada mata yang dibatasi oleh pupil (bagian pusat mata yang berwarna hitam) dan sclera (bagian putih dari mata). Kelebihan dari iris yang Jurnal Sains dan Teknologi | 25 
menjadikannya salah satu biometrik dengan tingkat akurasi yang tinggi adalah seumur hidup tekstur iris yang dimiliki seseorang akan stabil, iris merupakan organ internal yang dapat terlihat secara eksternal, iris dari dua orang kembar identik atau iris mata kanan dan kiri dari seorang individu sangat berbeda dan tidak saling berhubungan, iris memiliki struktur fisik yang kaya dan dapat menyediakan banyak data (Tang, Han, \& Zhang, 2009).

Tahap pengenalan iris yang seringkali menjadi objek penelitian adalah segmentasi iris. Salah satu metode yang sering digunakan dalam segmentasi iris adalah transformasi lingkaran Hough seperti yang dilakukan oleh Masek, yang mengkombinasikannya dengan metode deteksi tepi Canny (Masek, 2003). Namun, dengan metode tersebut terkadang akurasi wilayah pupil dan iris yang diperoleh tidak sesuai, hal ini dikarenakan kedua wilayah tersebut sebenarnya tidak berbentuk lingkaran sempurna, sedangkan transformasi lingkaran Hough menggunakan template lingkaran dengan bentuk yang sempurna untuk mencari wilayah pupil dan iris yang diasumsikan berbentuk lingkaran sempurna.

Teknik segmentasi yang memiliki kemampuan beradaptasi dengan solusi target adalah active contour atau sering disebut pula dengan istilah snake model. Pada teknik ini, suatu active contour (snake) yang terdiri dari himpunan titik koordinat akan mengitari fitur target (fitur yang akan diekstraksi). Cara kerjanya bisa dianalogikan seperti menemukan suatu bentuk dengan menggunakan balon, dalam hal ini balon akan melingkupi bentuk yang akan dicari. Udara di dalam balon kemudian dikeluarkan sedikit-demi sedikit hingga ukuran balon akan menyusut. Penyusutan pada balon akan berhenti pada saat ukuran balon telah sesuai dengan bentuk yang dicari. Dari ilustrasi tersebut dapat diketahui bahwa pencarian solusi dengan menggunakan snake model diekspresikan dengan proses meminimumkan fungsi tujuan (Nixon \& Aguado, 2008). Namun, terdapat kelemahan dari snake model ini, yakni snakes seringkali terjebak pada keadaan minimum lokal sehingga akan mempengaruhi solusi yang dihasilkan. Particle swarm optimization (PSO) merupakan teknik optimasi yang didasarkan pada perilaku sosial kawanan burung. Teknik ini diharapkan mampu mengatasi kelemahan dari snake model dengan cara mengoptimasi proses meminimumkan fungsi tujuan dalam snake model sehingga solusi yang dihasilkan dapat lebih optimal. Pemilihan teknik PSO didasarkan pada ulasan yang dilakukan oleh Kaur dan Singh yang menyimpulkan bahwa PSO yang dikombinasikan dengan metode lain seperti PSO-thresholding, PSO-berbasis fuzzy, PSO-algoritma genetika, PSO-berbasis wavelet, PSO-berbasis clustering, PSOberbasis rough set, dan PSO-berbasis jaringan syaraf tiruan akan menghasilkan pendekatan yang lebih efektif, karena pada dasarnya PSO adalah metode yang sangat tangguh (powerful) (Kaur \& Singh, 2012).

Berdasarkan latar belakang yang telah diungkapkan tersebut, penelitian mengenai pengenalan iris ini menggunakan pendekatan berbasis snake model yang dioptimasi dengan PSO untuk tahapan segmentasi. Ekstraksi ciri terhadap wilayah iris yang diperoleh dari tahap segmentasi akan menggunakan filter wavelet Gabor 2-D karena filter ini mampu menyediakan representasi gabungan yang optimal dari sinyal dalam domain spasial dan frekuensi. Hasil dari filter Gabor akan didemodulasi dengan menggunakan quadrature 2-D Gabor untuk menghasilkan iris code yang merupakan informasi pembeda (fitur ciri) iris yang telah dimampatkan. Proses identifikasi dilakukan dengan menggunakan metode klasifikasi berbasis nearest neighbor, yakni metode K-NN. Metode tersebut telah terbukti sebagai algoritma pengenalan yang sederhana dan tangguh, dengan aturan keputusan yang memiliki kinerja yang baik mengingat bahwa tidak tersedia pengetahuan eksplisit dari data (Choudhary, Singh, \& Tiwari, 2013).

\section{METODE}

Pada penelitian ini, data set yang digunakan adalah MMU Iris Database yang dikembangkan oleh Multimedia University di Malaysia. Data set ini terdiri dari 450 citra 
iris dengan setiap subjek memiliki 2 kelompok citra iris yang berasal dari iris kanan dan kiri. Masing-masing iris kanan dan kiri menghasilkan 5 citra iris. Seluruh citra pada data set tersebut merupakan citra grayscale 24 bit dengan format BMP dan berukuran 320x240 piksel (Zeng, n.d.). Pada Gambar 1 ditampilkan beberapa contoh dari citra iris yang berasal dari MMU Iris Database.
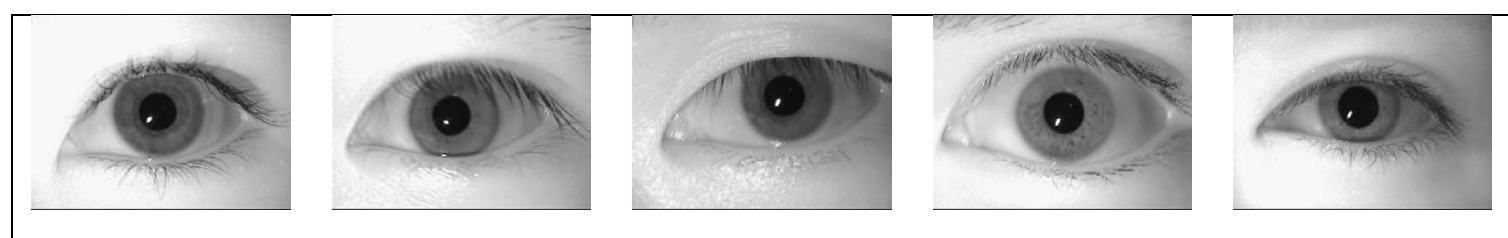

Gambar 1. Citra MMU Iris Database

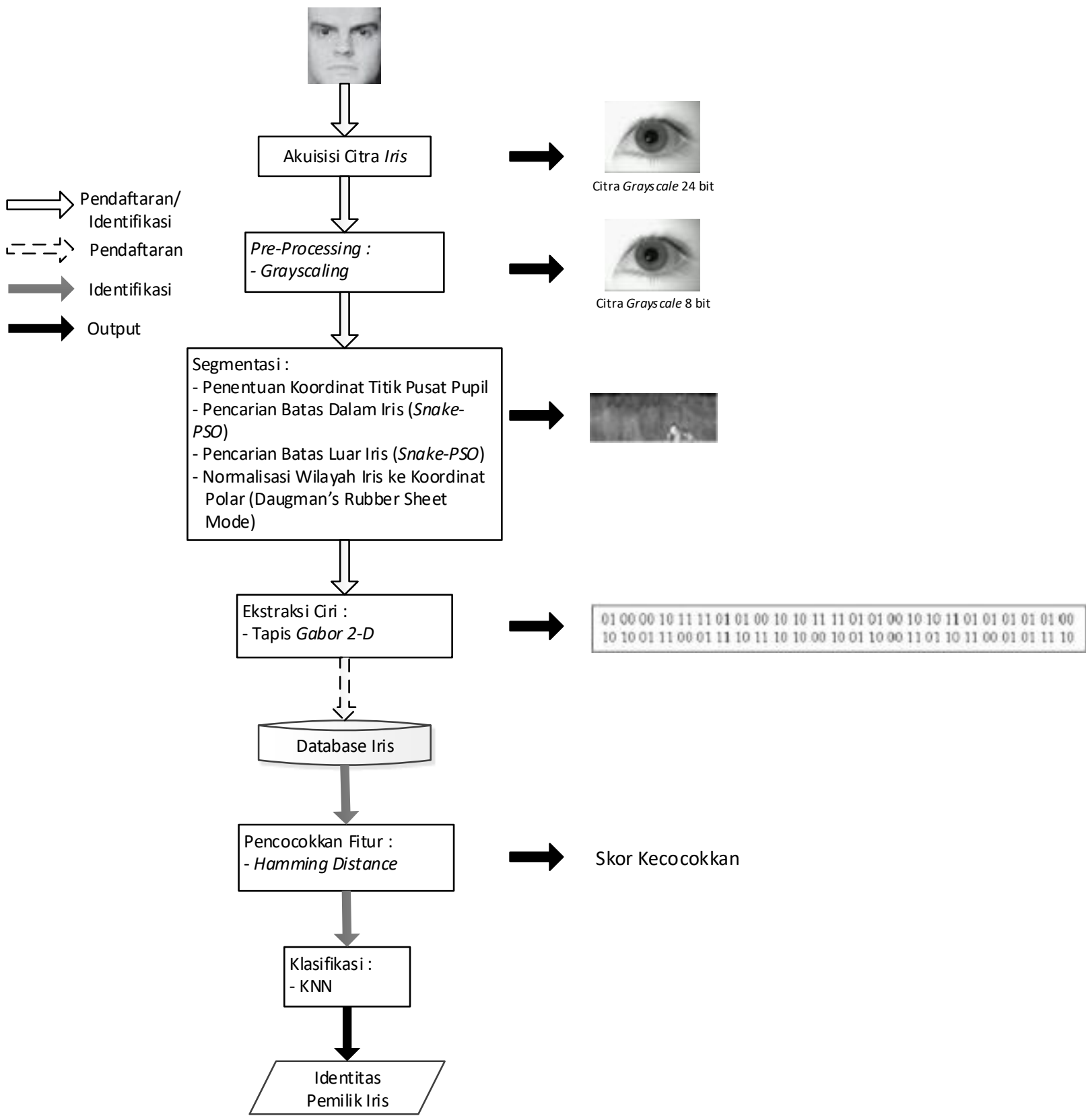


Gambar 2. Alur Kerja Sistem Identifikasi Biometrik

Alur kerja dari sistem identifikasi ini diawali dengan akuisisi citra iris (akuisisi tidak langsung). Citra iris hasil akuisisi merupakan citra grayscale 24 bit. Untuk mempermudah pemrosesan selanjutnya, citra iris melalui tahapan preprocessing untuk mengubahnya menjadi citra grayscale 8 bit berdasarkan nilai rata-rata dari ketiga channel warna dengan bobot channel red, green, dan blue berturut-turut adalah 0,2989; 0,5870; 0,1140 . Ketiga bobot didasarkan pada fungsi rgb2gray pada MATLAB. Citra hasil dari tahap pre-processing selanjutnya melalui tahap segmentasi. Tahap ini terdiri dari penentuan koordinat titik pusat pupil, pencarian batas dalam iris dan pencarian batas luar iris dengan snake$P S O$, serta normalisasi wilayah iris ke koordinat polar dengan Daugman's rubber sheet model. Citra iris ternormalisasi selanjutnya diproses melalui ekstraksi ciri dengan tapis Gabor 2-D untuk menghasilkan iris code. Iris code inilah yang digunakan dalam tahap identifikasi untuk mengetahui identitas citra iris yang diuji. Gambar 2 menunjukkan alur kerja selengkapnya dari sistem identifikasi biometrik iris.

Proses penghitungan titik pusat pupil bertujuan untuk menghasilkan titik pusat yang digunakan pada saat inisialisasi snake di proses segmentasi. Lokasi titik pusat yang dihasilkan akan menentukan posisi koordinat control points yang akan membentuk snake. Pada proses penghitungan titik pusat pupil, input yang digunakan adalah citra grayscale 8 bit yang dihasilkan dari tahap pre-processing. Output yang dihasilkan dari proses ini berupa koordinat titik pusat pupil. Langkah-langkah yang dilakukan dalam penghitungan titik pusat pupil adalah sebagai berikut:

1. Pembentukan histogram citra yang telah dikonversi menjadi citra grayscale

2. Penentuan nilai threshold berdasarkan hasil dari langkah 1 dengan mengambil nilai tengah dari histogram citra

3. Pengambangan citra grayscale yang merupakan output dari proses akuisisi citra dengan nilai threshold yang dihasilkan dari langkah 2

4. Penandaan komponen terhubung dengan 4-connected untuk mengisi wilayah citra yang kosong (berongga)

5. Penerapan tapis median untuk mengurangi noise pada citra

6. Penandaan komponen terhubung dengan 8-connected untuk menandai kandidat wilayah pupil

7. Penentuan koordinat titik pusat pupil

Batas dalam iris merupakan batas antara wilayah pupil dengan wilayah iris. Titik-titik koordinat yang merupakan batas dalam iris dicari dengan menggunakan snake model-PSO. Koordinat titik pusat pupil yang telah diperoleh digunakan untuk menentukan posisi koordinat control points pada inisialisasi snake. Output yang dihasilkan dari proses ini berupa titik-titik koordinat yang menjadi batas dalam iris. Batas luar iris merupakan batas antara wilayah iris dengan wilayah sclera. Titik-titik koordinat yang merupakan batas luar iris juga dicari dengan menggunakan snake model-PSO. Output yang dihasilkan dari proses ini berupa titik-titik koordinat yang menjadi batas luar iris. Langkah-langkah yang dilakukan dalam pencarian batas dalam dan luar iris adalah sebagai berikut:

1. Penentuan koordinat snake control points dengan memanfaatkan persamaan parametrik lingkaran sebagai berikut:

$$
\begin{aligned}
& x(t)=R \cos (t)+a \\
& y(t)=R \sin (t)+b
\end{aligned}
$$

Koordinat $x$ dan $y$ dicari berdasarkan parameter $t$, dengan jari-jari $R$, dan titik pusat $(a, b)$.

2. Penentuan nilai parameter $\alpha, \beta$, dan $\gamma$ :

a. Parameter $\alpha$ mengatur jarak antar titik pada snake (energi continuity)

b. Parameter $\beta$ mengatur variasi titik pada snake (energi curvature)

c. Parameter $Y$ mengatur kontribusi energi image

3. Penentuan nilai parameter swarmSize, maxlter, inertia, dan corr_factor:

a. Parameter swamsize berkaitan dengan ukuran swarm (jumlah 
partikel dalam sebuah swarm) pada setiap control point

b. Parameter maxlter berkaitan dengan jumlah maksimum iterasi yang dilakukan pada setiap swarm

c. Parameter inertia berkaitan dengan perilaku konvergen dari PSO

d. Parameter corr_factor berkaitan dengan seberapa jauh suatu partikel bergerak dalam sekali iterasi

4. Untuk setiap control point pada snake, lakukan langkah-langkah berikut:

a. Inisialisasi sebuah swarm dan alokasikan window pencarian untuk swarm tersebut

b. Tentukan nilai awal particle velocity

c. Tentukan nilai awal particle best value

d. Untuk setiap partikel pada swarm, lakukan langkah-langkah berikut:

i. Perbarui posisi setiap partikel dengan menggunakan:

Present $X[][d]+v[][d]$

Posisi partikel saat ini dinotasikan dengan Present $X[][d], \quad$ dan $v[][d]$ sebagai particle velocity.

ii. Hitung energi continuity dengan menggunakan:

$$
\begin{aligned}
& \left|\frac{\mathrm{d} \mathbf{v}_{s}}{\mathrm{~d} s}\right|^{2}=\mid \sum_{i=0}^{S-1}\left\|\mathbf{v}_{i}-\mathbf{v}_{i+1}\right\| / S- \\
& \left\|\mathbf{v}_{S}-\mathbf{v}_{S+1}\right\| \mid \\
& \quad= \\
& \sum_{i=0}^{S-1} \mid \sqrt{\left(\mathbf{x}_{i}-\mathbf{x}_{i+1}\right)^{2}+\left(\mathbf{y}_{i}-\mathbf{y}_{i+1}\right)^{2}} / \\
& S- \\
& \sqrt{\left(\mathbf{x}_{S}-\mathbf{x}_{S+1}\right)^{2}+\left(\mathbf{y}_{S}-\mathbf{y}_{S+1}\right)^{2}} \mid
\end{aligned}
$$

iii. Hitung energi curvature dengan menggunakan:

$$
\begin{aligned}
& \left|\frac{\mathrm{d}^{2} \mathbf{v}_{s}}{\mathrm{~d} s^{2}}\right|^{2}=\left|\left(\mathbf{v}_{s+1}-2 \mathbf{v}_{s}+\mathbf{v}_{s-1}\right)\right|^{2} \\
& =\left(\mathbf{x}_{s+1}-2 \mathbf{x}_{s}+\mathbf{x}_{s-1}\right)^{2}+ \\
& \left(\mathbf{y}_{s+1}-2 \mathbf{y}_{s}+\mathbf{y}_{s-1}\right)^{2}
\end{aligned}
$$

iv. Hitung energi image dengan menggunakan:

$E_{\text {img }}=\left\|\nabla\left[G_{\sigma}(x, y) * I(x, y)\right]\right\|^{2}(6)$ dengan, $G_{\sigma}(x, y)$ adalah matriks tapis Gaussian pada koordinat $(x, y)$ dan $I(x, y)$ adalah matriks citra input pada koordinat $(x, y)$. v. Lakukan normalisasi untuk setiap nilai energi continuity, energi curvature, dan energi image. Nilai energi continuity dan curvature dibagi dengan nilai energi terbesar pada wilayah ketetanggaan sehingga kedua nilai energi tersebut berada pada rentang nilai $[0,1]$. Khusus untuk energi image dinormalisasi dengan menggunakan:

$$
\begin{aligned}
& \operatorname{location}(x, y)= \\
& \frac{(\min -\operatorname{mag}(x, y))}{(\max -\min )}
\end{aligned}
$$

dengan, $\min$ adalah nilai minimum gradien di wilayah neighborhood, max adalah nilai maksimum gradien di wilayah neighborhood, dan $\operatorname{mag}(x, y)$ adalah magnitudo gradien dari point saat ini.

vi. Hitung nilai fitness berupa energi snake dengan menggunakan:

$$
\begin{aligned}
& E_{\text {snake }}(x, y)=\alpha\left(s_{i}\right) E_{\text {cont }}(x, y)+ \\
& \beta\left(s_{i}\right) E_{\text {curv }}(x, y)+ \\
& \gamma\left(s_{i}\right) E_{\text {img }}(x, y)
\end{aligned}
$$

vii. Perbarui particle best position dan particle best value berdasarkan:

If current_value < PBEST [] then PBEST [] = current_value PBESTX []$[d]=$ current_position (9)

viii. Temukan global best position pada swarm berdasarkan:
If current_value <
PBEST [GBEST] then
GBEST $=$ particle's_array_index (10)

ix. Untuk setiap partikel pada swarm, perbarui nilai particle velocity dengan menggunakan: $V[][d]=V[][d]+A C C_{-} C O N S T *$ rand ()$*(P B E S T x[][d]-$ Present $X[][d])+A C C_{-} C O N S T *$ $\operatorname{rand}() *(P B E S T x[G B E S T][d]-$ Present $X[\rceil[d])$

e. Ulangi langkah b hingga jumlah iterasi maksimum tercapai

f. Pindahkan posisi control point saat ini ke global best position

5. Ulangi langkah 4 hingga jumlah maksimum iterasi tercapai atau jumlah Jurnal Sains dan Teknologi | 29 
control point yang berpindah posisi kurang dari nilai yang ditentukan

Hasil dari pencarian batas dalam dan luar iris berupa himpunan titik koordinat yang selanjutnya dinormalisasi ke koordinat polar yang bertujuan untuk mengubah koordinat batas-batas iris dari koordinat kartesian menjadi koordinat polar. Proses ini dilakukan dengan menggunakan Daugman's rubber sheet model (Arvacheh, n.d.). Output dari proses ini berupa array 2$D$ dengan dimensi horizontal diperoleh dari resolusi angular dan dimensi vertikal dari resolusi radial.

Proses ekstraksi ciri dilakukan dengan menggunakan tapis Gabor 2-D. Output yang dihasilkan dari proses ini berupa 8 iris code dengan panjang tertentu yang terdiri dari kombinasi angka biner. Kedelapan iris code tersebut terdiri dari 4 iris code untuk bagian real dengan masingmasing iris code dihasilkan dari $\theta$ bernilai $90^{\circ}, 45^{\circ}, 0^{\circ}$, dan $-45^{\circ}$; dan bagian imaginary dengan masing-masing iris code dihasilkan dari $\theta$ bernilai $90^{\circ}, 45^{\circ}, 0^{\circ}$, dan $-45^{\circ}$. Langkah-langkah yang dilakukan dalam proses ekstraksi ciri adalah sebagai berikut:

1. Pembentukan tapis Gabor 2-D dengan persamaan:

$G(x, y, \theta, u, \sigma)=$

$\frac{1}{2 \pi \sigma^{2}} \exp \left\{-\frac{x^{2}+y^{2}}{2 \sigma^{2}}\right\} \exp \{2 \cdot \pi \cdot i(u \cdot x \cdot \cos \theta+$

u.y. $\sin \theta)\}$

dengan, $i$ bernilai $\sqrt{-1}, u$ adalah frekuensi dari gelombang sinusoidal, $\theta$ adalah kontrol terhadap orientasi dari fungsi Gabor, $\sigma$ adalah standar deviasi dari Gaussian envelope, dan $x, y$ adalah koordinat dari tapis Gabor.

2. Wilayah iris dikonvolusi dengan tapis yang dihasilkan dari langkah 1

3. Pemisahan bagian real dan imaginary dari hasil konvolusi pada langkah 2. Pemisahan ini menghasilkan bagian real dan imaginary yang masing-masing memiliki $\theta$ bernilai $90^{\circ}, 45^{\circ}, 0^{\circ}$, dan $-45^{\circ}$.

4. Untuk setiap bagian real lakukan pembentukan iris code dengan ketentuan berikut:

$b r=1$ if $\operatorname{Re}[\tilde{G}[x, y, \theta, \sigma] * I] \geq 0$

$b r=0$ if $\operatorname{Re}[\tilde{G}[x, y, \theta, \sigma] * I]<0$

\section{HASIL DAN PEMBAHASAN}

Pada pencarian batas dalam iris dilakukan percobaan terhadap 39 individu dari 45 individu yang tersedia pada $M M U$ Iris Database. Enam individu tidak dapat digunakan untuk percobaan karena titik pusat pupil tidak ditemukan. Citra yang digunakan untuk setiap individu berjumlah 10 buah yang terdiri dari 5 buah citra mata kiri dan 5 buah citra mata kanan. Total citra yang digunakan dalam percobaan ini adalah 390 buah citra. Pada Gambar 3 ditampilkan hasil percobaan dari pencarian batas dalam iris menggunakan Snake Model-PSO. Pada metode Snake Model$P S O$, sebagian besar batas dalam iris ditemukan pada iterasi ke-72. Nilai parameter snake yang digunakan adalah $\alpha$ $=0,5 ; \beta=2.2 ; \gamma=0,5$.

Total citra yang digunakan dalam pencarian batas luar iris sama halnya dengan pencarian batas dalam iris, yakni sejumlah 390 buah citra. Pada metode Snake Model-PSO, sebagian besar batas luar iris ditemukan pada iterasi ke-72. Nilai parameter snake yang digunakan adalah $\alpha$ $=0,5 ; \beta=2,2 ; y=0,5$. Pada Gambar 4 ditampilkan hasil percobaan dari pencarian batas dalam iris menggunakan Snake Model-PSO.

Hasil normalisasi wilayah iris ke koordinat polar ditunjukkan oleh Gambar 5. Ukuran dimensi horizontal yang digunakan adalah 50, yakni berdasarkan jumlah control points yang digunakan pada saat pencarian batas dalam dan luar iris, sedangkan ukuran dimensi vertikal yang digunakan adalah 20. Nilai parameter $\rho$ berkaitan dengan dimensi vertikal (resolusi radial). Oleh karena nilai parameter $\rho$ ditentukan berada dalam interval $[0,1]$, maka jarak antar nilai yang digunakan adalah (1/dimensi vertikal). Untuk nilai parameter $\theta$ menggunakan urutan posisi control points pada snake, yakni $1,2,3, \ldots$, 50. Nilai parameter $x_{p}(\theta)$ dan $y_{p}(\theta)$ diperoleh dari koordinat posisi control points dari hasil pencarian batas dalam iris (batas pupil). Nilai parameter $x_{i}(\theta)$ dan $y_{i}(\theta)$ diperoleh dari koordinat posisi control points dari hasil pencarian batas luar iris (batas iris). 
Iris code merupakan kode biner yang unik dan dihasilkan dari fitur real dan imaginary dari wilayah iris yang telah dinormalisasi. Iris code yang dihasilkan berukuran 1000 bytes yang dihasilkan oleh fitur iris berukuran $50 \times 20$ piksel seperti yang ditunjukkan pada Gambar 6 .

Pengujian probabilitas kesalahan pencocokkan dilakukan dengan menghitung nilai FMR dan FNMR (Dunstone \& Yager, 2009). Penghitungan kedua nilai tersebut dilakukan untuk setiap kombinasi nilai $\theta$ dan jenis pergeseran bit. Jumlah data referensi yang digunakan adalah 234 iris code dengan komposisi jumlah data dari iris kiri dan iris kanan masing-masing adalah 117 iris code. Penghitungan skor kemiripan dilakukan untuk setiap kombinasi pasangan data referensi yang berjumlah
6786 penghitungan dengan komposisi 6669 penghitungan pada sampel dari pengguna yang berbeda dan 117 penghitungan pada sampel dari pengguna yang sama. Skor kemiripan antara data referensi dan data uji diperoleh dengan cara mencocokkan setiap bit data pada iris code referensi dengan iris code uji. Skor 1 akan diberikan pada setiap pasangan bit yang berbeda dan selanjutnya dari nilai total tersebut dicari nilai rataratanya. Semakin kecil nilai yang diperoleh, makan semakin tinggi kemiripannya.

Tabel 1 menunjukkan bahwa tingkat akurasi pencocokan tertinggi untuk iris kiri terjadi ketika sudut orientasi yang digunakan adalah $-45^{\circ}$ dan jenis pergeseran bit yang digunakan adalah right. Hasil tersebut

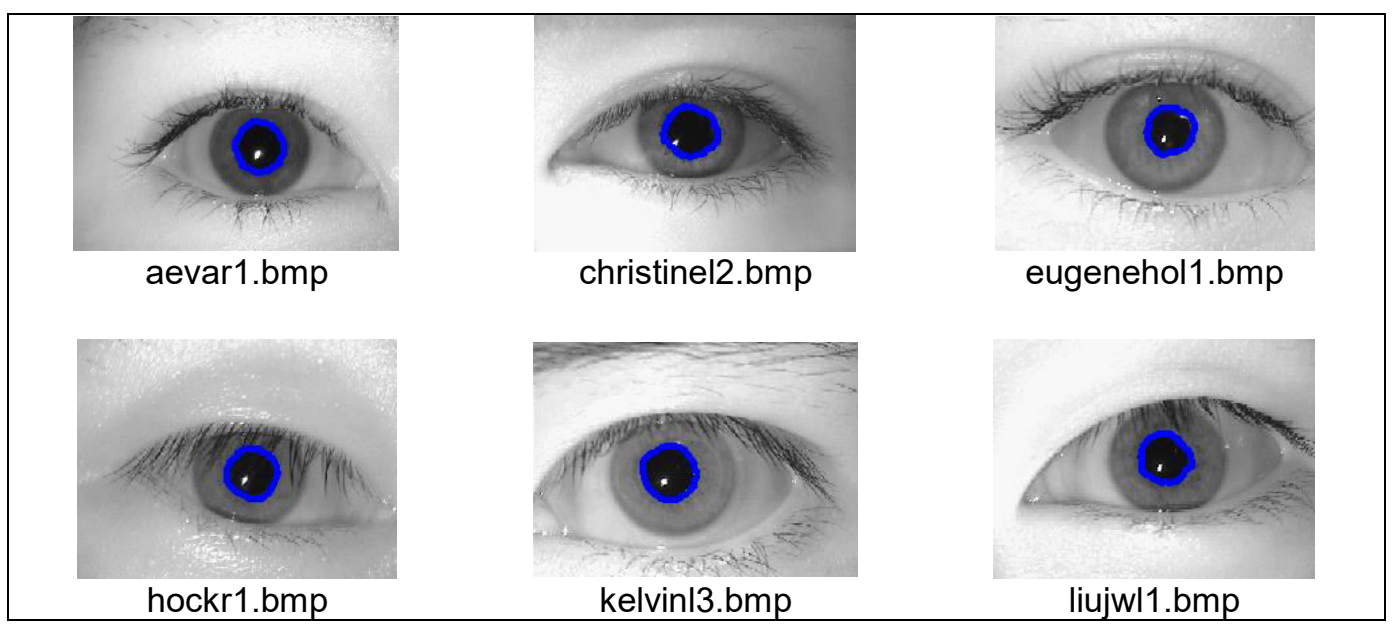

Gambar 3. Hasil Percobaan Pencarian Batas Dalam Iris dengan Snake Model-PSO

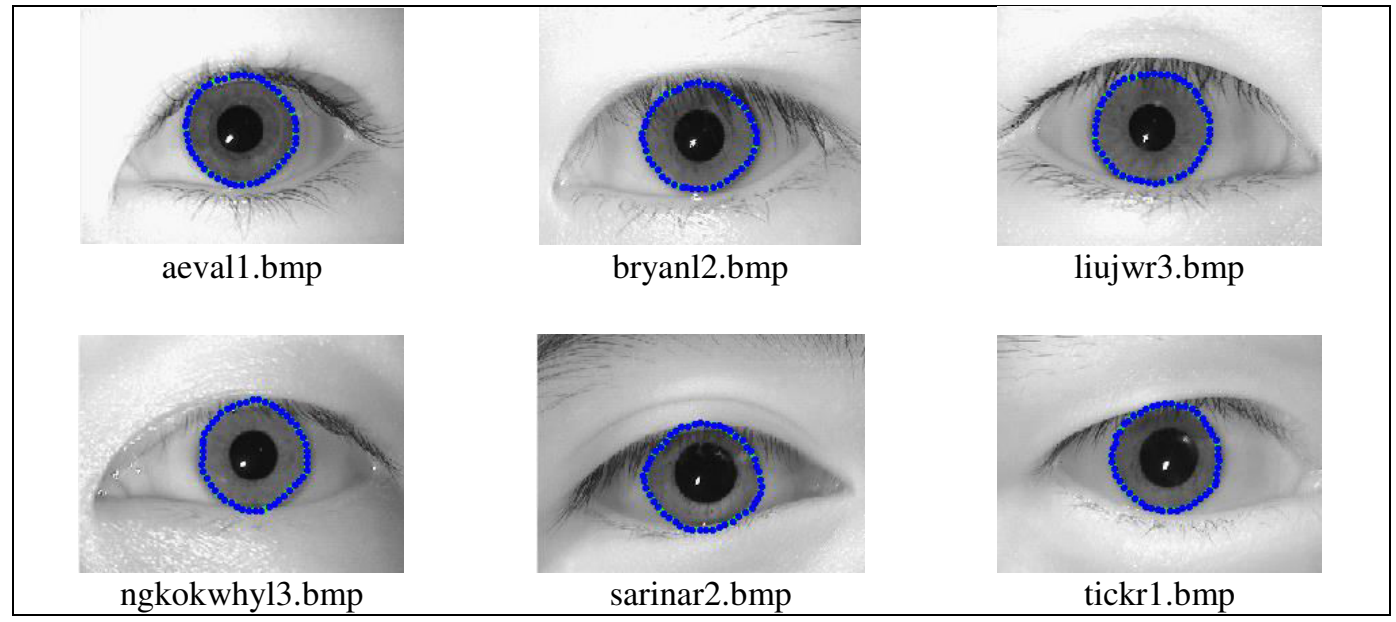

Gambar 4. Hasil Percobaan Pencarian Batas Luar Iris dengan Snake Model-PSO 


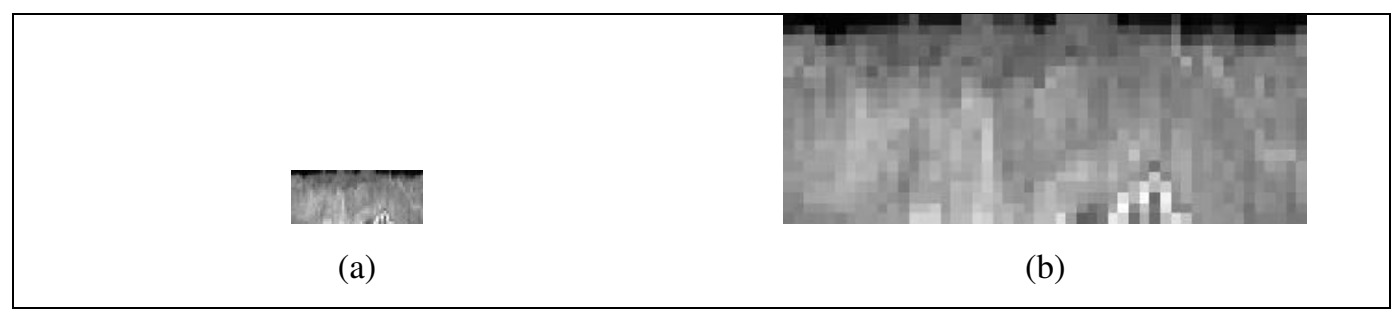

Gambar 5. Normalisasi Wilayah Iris ke Koordinat Polar

(a) Ukuran 50×20 Piksel (b) Diperbesar ke Ukuran 200×80 Piksel

menunjukkan bahwa fitur iris yang dihasilkan dengan sudut orientasi $-45^{\circ}$ pada database iris kiri dapat merepresentasikan karakteristik setiap iris dengan lebih baik dibandingkan dengan sudut orientasi $90^{\circ}$, $45^{\circ}$, dan $0^{\circ}$. Selain itu, jenis pergeseran bit right menunjukkan bahwa fitur iris uji yang dihasilkan cenderung mengalami pergeseran bit ke arah kiri. Hal ini berkaitan dengan adanya perubahan posisi mata sampel ketika proses akuisisi citra. Gambar 7 menunjukkan bahwa ketika nilai ambang $(T)$ berada pada posisi 0,368 , sistem menghasilkan tingkat kesalahan minimum dengan nilai $F M R$ sebesar $3,6737 \%$ dan nilai FNMR sebesar $4,2735 \%$ untuk pencocokan iris kiri. Hal ini berarti bahwa terdapat $3,6737 \%$ kesalahan penentuan kecocokan pada penghitungan skor kemiripan untuk sampel data latih yang berasal dari individu berbeda dan 4,2735\% kesalahan penentuan ketidakcocokan pada penghitungan skor kemiripan untuk sampel data uji yang berasal dari individu yang sama.

001110011100110001100110011100011100111000111000110011100011000110011100110011100 011000111000111000100011100111001110011001100011000111000111000110001100011100111 001100011001100111000110000011001110001100011000110001100111001100110001110010011 001110011000111001110011100110011001110011100110110001100111000110001110011000110 011001100011000100110011101111001110001100011001100110011100011001101100011001110 001100011100111001101100011000111001111100111001110011100011100111001001100111000 110001111001110001110011100011100111000011100111000110001110001110001100011000011 100111100011000111001110001110011110011100111000011000111000111000110001110011100 111110011000111000011001110000111001110001100011001101110011000110000111001100100 111001110011100011001001100111001110000110011001100110001110011100110010001100110 001100001100011001100110001100011000110010011100110011100011100110001000110001100 111001100100011001110011000011000110011001110011100110001101100111001100111000111

Gambar 6. Iris Code

Tabel 1. Tingkat Akurasi Pencocokan (dalam \%) Iris Kiri

\begin{tabular}{cccc}
\hline \multirow{2}{*}{} & \multicolumn{3}{c}{ Jenis Pergeseran Bit } \\
\cline { 2 - 4 } & Tidak Ada & Kanan & Kiri \\
\hline $\mathbf{9 0}^{\circ}$ & 69,1108 & 72,1098 & 65,0772 \\
$\mathbf{4 5}^{\circ}$ & 41,9103 & 84,2405 & 29,2248 \\
$\mathbf{0}^{\circ}$ & 10,3614 & 91,363 & 7,5574 \\
$\mathbf{- 4 5}^{\mathbf{0}}$ & 39,1813 & $\mathbf{9 2 , 0 5 2 8}$ & 44,6844 \\
\hline
\end{tabular}




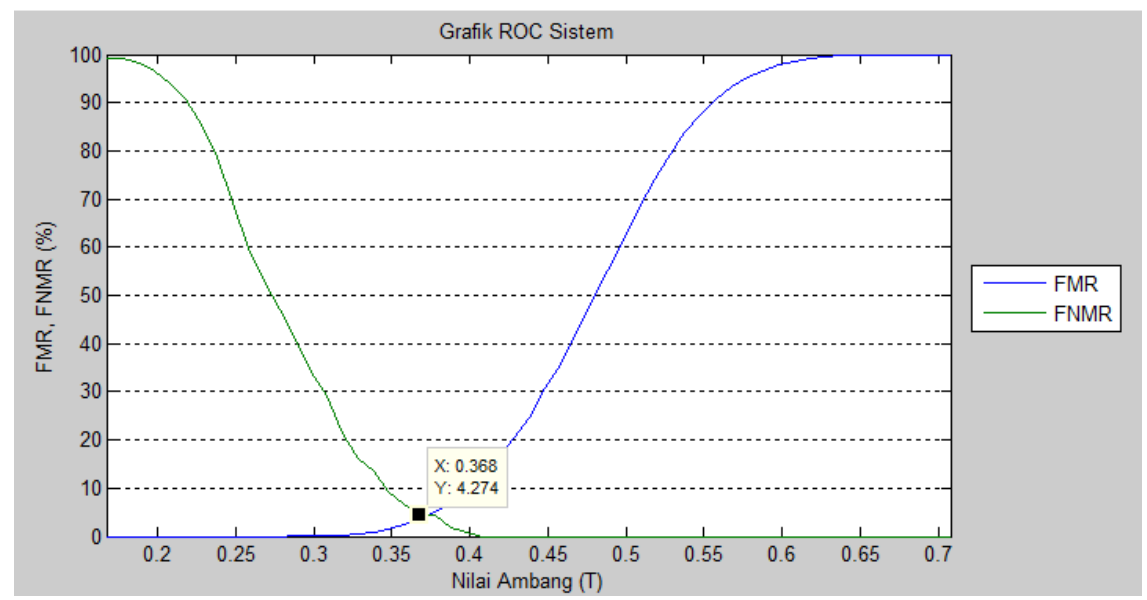

Gambar 7. Grafik ROC Sistem untuk Iris Kiri dengan $\theta=-45^{\circ}$ dan Jenis Pergeseran Bit $=$ Right

Tabel 2 menunjukkan bahwa tingkat akurasi pencocokan tertinggi untuk iris kanan terjadi ketika sudut orientasi yang digunakan adalah $45^{\circ}$ dan jenis pergeseran bit yang digunakan adalah right. Hasil tersebut menunjukkan bahwa fitur iris yang dihasilkan dengan sudut orientasi $45^{\circ}$ pada database iris kanan dapat merepresentasikan karakteristik setiap iris dengan sangat baik. Selain itu, jenis pergeseran bit right menunjukkan bahwa fitur iris uji yang dihasilkan cenderung mengalami pergeseran bit ke arah kiri. Hal ini berkaitan dengan adanya perubahan posisi mata sampel ketika proses akuisisi citra.

Kedua hasil yang ditunjukkan oleh pencocokan iris kiri dan kanan menunjukkan bahwa jenis pergeseran bit memiliki pengaruh yang cukup besar dalam

Tabel 2. Tingkat Akurasi Pencocokan (dalam \%) Iris Kanan

\begin{tabular}{cccc}
\hline \multirow{\theta}{*}{} & \multicolumn{3}{c}{ Jenis Pergeseran Bit } \\
\cline { 2 - 4 } & Tidak Ada & Kanan & Kiri \\
\hline $\mathbf{9 0}^{\circ}$ & 93,7472 & 96,7611 & 93,5523 \\
$\mathbf{4 5}^{\circ}$ & 61,0586 & $\mathbf{1 0 0}$ & 51,9568 \\
$\mathbf{0}^{\circ}$ & 12,3257 & 96,4312 & 15,8045 \\
$\mathbf{- 4 5}^{\mathbf{0}}$ & 53,6962 & 96,6262 & 63,6527 \\
\hline
\end{tabular}

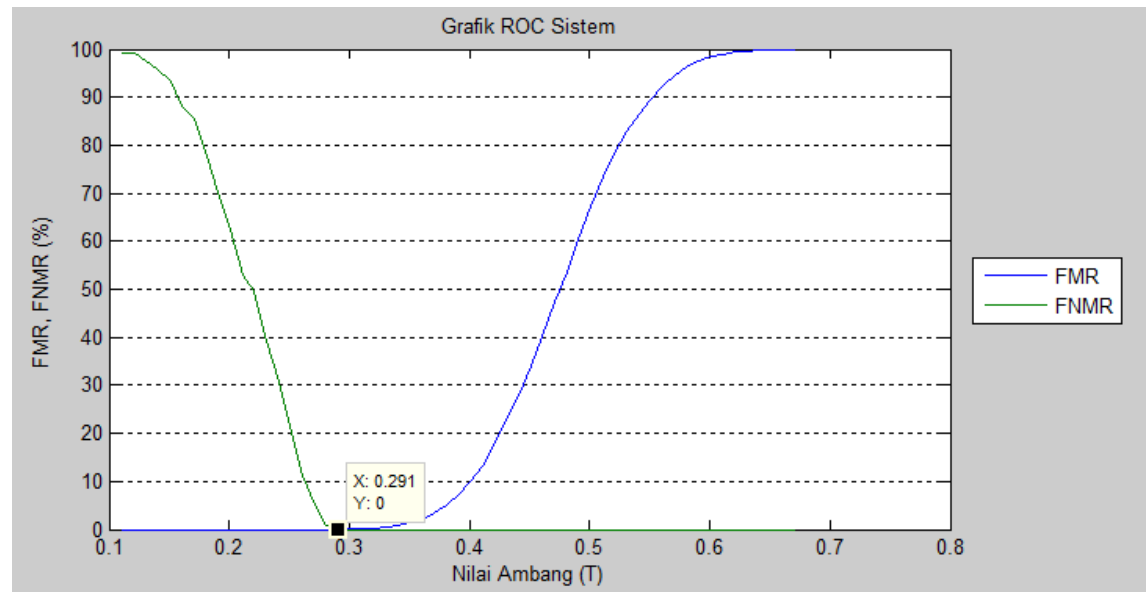

Gambar 8. Grafik ROC Sistem untuk Iris Kanan dengan $\theta=-45^{\circ}$ dan Jenis Pergeseran Bit $=$ Right 
menentukan tingkat akurasi pencocokan sistem. Hal tersebut berkaitan dengan tidak adanya posisi mata standar yang ditentukan terhadap para individu yang dijadikan sebagai sampel ketika akuisisi citra sehingga terdapat kemungkinan pergeseran posisi ketika melakukan sejumlah pengambilan citra pada suatu sesi. Gambar 8 menunjukkan bahwa ketika nilai ambang $(T)$ berada pada posisi 0,291 , sistem tidak menghasilkan kesalahan penentuan kecocokan, baik untuk penghitungan skor kemiripan untuk sampel data latih yang berasal dari individu berbeda dan penghitungan skor kemiripan untuk sampel data latih yang berasal dari individu yang sama. Hal ini ditandai dengan nilai $F M R$ dan FNMR berturut-turut sebesar $0 \%$ untuk pencocokan iris kanan. Kedua hasil yang ditunjukkan oleh pencocokan iris kiri dan kanan menunjukkan bahwa pemilihan nilai ambang $(T)$ mempengaruhi nilai FMR dan FNMR dari sistem. Peningkatan nilai FMR dan FNMR akan menyebabkan penurunan kinerja pencocokan sistem, sebaliknya penurunan nilai $F M R$ dan FNMR akan menyebabkan peningkatan kinerja pencocokan sistem.

Tingkat keberhasilan sistem dalam menghasilkan keputusan yang benar terhadap identitas pemilik iris diketahui melalui pengujian akurasi keputusan. Pengujian akurasi keputusan dilakukan terhadap hasil identifikasi yang dilakukan berdasarkan kombinasi nilai $\theta$, jenis pergeseran, dan nilai $K$. Jumlah keseluruhan data uji yang digunakan dalam pengujian ini adalah sebanyak 156 citra. Jumlah data uji tersebut diperoleh dari 39 individu. Setiap individu memiliki 4 data uji dengan komposisi 2 citra iris kanan dan 2 citra iris kiri. Tabel 3 menunjukkan bahwa tingkat akurasi keputusan tertinggi untuk pengujian dengan menggunakan data uji yang dihasilkan oleh iris kiri terjadi ketika nilai $K$ yang digunakan adalah 1 dan 3 . Sedangkan pada pengujian dengan menggunakan data uji yang dihasilkan oleh iris kanan, tingkat akurasi keputusan tertinggi terjadi ketika nilai $K$ yang digunakan adalah 1. Parameter $K$ menunjukkan jumlah sampel pelatihan (data referensi) yang merupakan tetangga terdekat ke sampel uji (data uji). Kedua hasil pengujian tersebut menunjukkan bahwa semakin besar nilai $K$ yang digunakan, maka tingkat akurasi keputusan yang dihasilkan oleh sistem dalam mengenali kepemilikan iris akan semakin rendah. Hasil tersebut dapat disebabkan oleh citra iris yang digunakan kurang menampilkan pola iris dengan detail, sehingga kemiripan iris code dalam beberapa bagian masih mungkin terjadi. Selain itu, semakin besar nilai $K$ yang digunakan, maka himpunan $K$ tetangga terdekat ke data uji akan memiliki skor kemiripan yang nilainya semakin besar dan berpeluang melebihi nilai ambang ( $T$ ) yang telah ditentukan sehingga dapat mengakibatkan tidak dikenalinya identitas pemilik iris (unknown).

Tabel 3. Tingkat Akurasi Keputusan (\%)

\begin{tabular}{lccc}
\hline \multirow{2}{*}{ Database } & \multicolumn{3}{c}{$\mathbf{k}$} \\
\cline { 2 - 4 } & $\mathbf{1}$ & $\mathbf{3}$ & $\mathbf{5}$ \\
\hline Iris Kiri & $\mathbf{9 1 , 0 2 5 6}$ & $\mathbf{9 1 , 0 2 5 6}$ & 85,8974 \\
Iris Kanan & $\mathbf{9 8 , 7 1 7 9}$ & 96,1538 & 89,7436 \\
\hline
\end{tabular}

Sistem identifikasi biometrik iris yang telah dibangun terdiri dari dua modul, yakni modul pendaftaran dan modul identifikasi. Pada pengujian waktu proses sistem, pengujian dilakukan pada kedua modul. Waktu proses yang dihasilkan untuk setiap modul merupakan waktu rata-rata dari keseluruhan proses yang dijalankan pada masing-masing modul.
Pada modul pendaftaran dilakukan pencatatan waktu proses untuk pencarian batas dalam iris, pencarian batas luar iris, dan pembentukan iris code seperti yang ditunjukkan pada Tabel 4. Pencatatan tersebut dilakukan untuk setiap citra iris yang digunakan sebagai data referensi maupun data uji. Rata-rata waktu proses modul pendaftaran adalah rata-rata waktu 
yang dibutuhkan untuk pencarian batas dalam iris, pencarian batas luar iris, dan pembentukan iris code untun setiap citra iris. Jumlah citra iris yang digunakan sebagai data referensi adalah 234 citra dengan komposisi jumlah data dari iris kiri dan iris kanan masing-masing adalah 117 citra. Jumlah citra iris yang digunakan sebagai data uji adalah 156 citra dengan komposisi jumlah data dari iris kiri dan iris kanan masing-masing adalah 78 citra. Jumlah keseluruhan citra iris yang digunakan pada modul pendaftaran adalah 390 citra.

Modul identifikasi terdiri dari dua sub modul, yakni pelatihan dan pengujian. Pada sub modul pelatihan tidak dilakukan pencatatan waktu proses. Pada sub modul pengujian waktu proses yang dicatat adalah rata-rata waktu yang dibutuhkan untuk melakukan sekali identifikasi. Jumlah data uji yang digunakan adalah 156 iris code dengan komposisi jumlah data dari iris kiri dan iris kanan masing-masing adalah 78 iris code. Tabel 5 menunjukkan rata-rata waktu proses sub modul pengujian. Lamanya waktu proses disebabkan oleh mekanisme $K-N N$ yang melakukan penghitungan skor kemiripan data uji terhadap setiap sampel yang terdapat pada data referensi. Sehingga untuk sekali identifikasi, penghitungan skor kemiripan dilakukan sebanyak 117 penghitungan.

Tabel 4. Rata-rata Waktu Proses Modul Pendaftaran (Detik)

\begin{tabular}{lcccc}
\hline \multirow{2}{*}{ Jenis Data } & \multicolumn{4}{c}{ Rata-rata Waktu Proses } \\
\cline { 2 - 5 } & $\begin{array}{c}\text { Pencarian } \\
\text { Batas Dalam } \\
\text { Iris }\end{array}$ & $\begin{array}{c}\text { Pencarian } \\
\text { Batas Luar } \\
\text { Iris }\end{array}$ & $\begin{array}{c}\text { Pembentukan } \\
\text { Iris Code }\end{array}$ & $\begin{array}{c}\text { Modul } \\
\text { Pendaftaran }\end{array}$ \\
\hline Data & 3,3105 & 2,8614 & 0,0754 & $\mathbf{6 , 2 4 7 3}$ \\
$\begin{array}{l}\text { Referensi } \\
\text { Data Uji }\end{array}$ & 3,3760 & 2,9267 & 0,0717 & $\mathbf{6 , 3 7 4 4}$ \\
\hline \multicolumn{4}{c}{ Rata-rata waktu proses } & $\mathbf{6 , 3 1 0 9}$ \\
\hline
\end{tabular}

Tabel 5. Rata-rata Waktu Proses Modul Pengujian (Detik)

\begin{tabular}{|c|c|c|c|c|}
\hline \multirow[b]{2}{*}{ Database } & \multicolumn{4}{|c|}{ Rata-rata Waktu Proses } \\
\hline & $\begin{array}{c}\text { Pencarian } \\
\text { Batas Dalam } \\
\text { Iris }\end{array}$ & $\begin{array}{l}\text { Pencarian } \\
\text { Batas Luar } \\
\text { Iris }\end{array}$ & Identifikasi & $\begin{array}{l}\text { Sub Modul } \\
\text { Pengujian }\end{array}$ \\
\hline Iris Kiri & 3,4865 & 2,8675 & 13,4091 & 19,7631 \\
\hline Iris Kanan & 3,3475 & 2,9398 & 14,9375 & 21,2248 \\
\hline \multicolumn{4}{|c|}{ Rata-rata waktu proses } & 20,494 \\
\hline
\end{tabular}

\section{SIMPULAN}

Sistem identifikasi ini menghasilkan persentase FMR sebesar $3,6737 \%$ dan FNMR sebesar $4,2735 \%$ untuk database iris kiri. Persentase FMR dan FNMR untuk database iris kanan menghasilkan nilai yang sama, yakni $0 \%$. Unjuk kerja sistem berdasarkan akurasi keputusan menghasilkan persentase terbaik sebesar 91, 0256\% untuk database iris kiri dan $98,7179 \%$ untuk database iris kanan. Ratarata waktu proses pada pendaftaran adalah 6,3109 detik, sedangkan pada identifikasi adalah 20,494 detik.
Adapun saran yang penulis harapkan dapat berguna untuk mendukung penelitian-penelitian selanjutnya yang berkaitan dengan topik identifikasi biometrik iris adalah penggunaan citra iris dengan detail iris yang lebih jelas untuk menjaga keunikan iris code yang dihasilkan. Selain berkaitan dengan sampel data, saran lainnya adalah mengenai penentuan nilai FRR (FNMR) dan FAR (FMR) yang digunakan pada sistem. Pada penelitian ini, tujuan sistem biometrik yang dibangun masih sebatas pengujian implementasi algoritma, sehingga penentuan nilai $F R R$ (FNMR) dan FAR (FMR) yang digunakan 
hanya mengacu pada hasil total nilai kesalahan minimum. Diharapkan pada penelitian selanjutnya, penentuan kedua nilai tersebut dapat disesuaikan dengan tujuan sistem biometrik yang dibangun, apakah sebagai aplikasi keamanan tingkat tinggi, aplikasi sipil, atau aplikasi forensik. Selain itu, terkait dengan waktu proses identifikasi yang masih terhitung cukup lama untuk kebutuhan sistem biometrik, diharapkan pada penelitian-penelitian selanjutnya dapat dihasilkan metodemetode yang mampu mempersingkat waktu proses pada Snake Model-PSO dan juga pada mekanisme $\mathrm{K}-\mathrm{NN}$.

\section{DAFTAR PUSTAKA}

Arvacheh, E. M. (n.d.). A Study of Segmentation and Normalization for Iris Recognition Systems. University of Waterloo.

Choudhary, D., Singh, A. K., \& Tiwari, S. (2013). A Statistical Approach for Iris Recognition Using K-NN Classifier. International Journal of Image, Graphics and Signal Processing, 5(4), 46-52.

https://doi.org/10.5815/ijigsp.2013.04.0 6

Dunstone, T., \& Yager, N. (2009). Biometric
System and Data Analysis: Design, Evaluation, and Data Mining. New York: Springer.

Kaur, A., \& Singh, M. D. (2012). An Overview of PSO- Based Approaches in Image Segmentation. International Journal of Engineering and Technology (IJET), 2(8), 1349-1358.

Masek, L. (2003). Recognition of Human Iris Patterns for Biometric Identification. University of Western Australia.

Nixon, M., \& Aguado, A. (2008). Feature Extraction \& Image Processing (Second Edi). London: Elsevier.

Putra, D. (2010). Pengolahan Citra Digital.

Tang, R., Han, J., \& Zhang, X. (2009). Efficient iris segmentation method with support vector domain description. Optica Applicata, 39(2), 365-374.

Zeng, A. (n.d.). Iris Recognition. Retrieved January 1, 2018, from http://www.cs.princeton.edu/ andyz/iri srecognition 